\title{
Gene diversity analysis of mitochondrial DNA, microsatellites and allozymes in landlocked Atlantic salmon
}

\author{
N. Tessier*, L. Bernatchez* ${ }^{*}$, P. Presa $\ddagger$ And B. Angers* \\ *Université Laval, Cité Universitaire, Dépt. Biologie (GIROQ). Ste-Foy, Québec, Canada, \\ G1K 7 P4 and $\ddagger$ Laboratoire de Génétique des Poissons, INRA, 78352, Jouy-en-Josas,
}

France

\begin{abstract}
This study investigates the patterns of genetic diversity detected in allozymes, mtDNA, and microsatellites, in order to assess their relative efficacy to differentiate sympatric landlocked salmon populations and to estimate changes in genetic diversity between wild and firstgeneration hatchery fish. Overall, the three genetic markers indicated a genetic differentiation between two sympatric populations of Lake Saint-Jean, Québec. MtDNA and microsatellites also showed significant differences between wild and first-generation hatchery fish originating from the same river. Allozyme analysis was the most limited approach due to the low genetic diversity detected and the necessity to kill specimens. Although low polymorphism was found in mtDNA, it was the most discriminant marker between wild populations. Microsatellite analysis appears to be a promising approach due to its high sensitivity in differentiating wild populations, in detecting changes in allele composition between wild and first-generation hatchery fish and its potential for increased resolution by augmenting the number of polymorphic loci. Given the benefits and disadvantages of the three methods, the combination of mtDNA and microsatellite analyses will best address our research objectives.
\end{abstract}

(1995 The Fisheries Society of the British Isles

Key words: conservation genetics; Atlantic salmon; stock identification; fishery management.

\section{INTRODUCTION}

Stocking is being used as a major management tool to enhance exploited fish populations facing declines in abundance. It should be designed to maintain both inter- and intra-population components of a species' genetic diversity. A better understanding of stock structure, as well as estimates of differentiation and the degree of natural gene exchange among populations, can provide guidelines to optimize population enhancement practices to conserve genetic resources (Ryman, 1991).

Many genetic approaches can provide information upon which to base management decisions. Allozyme analysis has been a method of choice for many management purposes (Ferguson, 1994). To a lesser extent, the analysis of mitochondrial DNA variation has also been used successfully (Billington \& Hebert, 1991; Bernatchez, 1994). More recently, the application of variable number of tandem repeats (VNTR) analysis has been introduced as a potentially powerful method for fine-scale studies of genetic diversity in fishes (Taggart \& Ferguson, 1990; Wright \& Bentzen, 1994). It is obvious from the literature that the relative usefulness of different methods depends largely upon the species and geographic scale to which they are applied, as well as the questions asked. Therefore, it is valuable to compare the information generated by different

$\dagger$ Author to whom correspondence should be addressed.

email: C788@music.ulaval.ca 
molecular approaches. Yet, this is rarely achieved (Carvalho \& Hauser, 1994).

Lake Saint-Jean is a moderate-sized lake $\left(1000 \mathrm{~km}^{2}\right)$ located in central Québec (approximately $200 \mathrm{~km}$ north of Québec city, Canada) which harbours landlocked Atlantic salmon Salmo salar L. Since the mid-1980s, several spawning runs have been declining to less than 30 spawning adults being counted in some. Consequently, a supportive-breeding programme has been undertaken in the early 1990s for the four major tributaries of the lake used for spawning. Recently we initiated a genetic study with the main objective of providing guidelines for the conservation of salmon genetic diversity in this lake. This preliminary study compares genetic diversity among the same samples using allozymes, mtDNA, and microsatellites, in order to assess their relative usefulness.

\section{MATERIALS AND METHODS}

Thirty-six wild spawning (not issued from stocking programmes) fish were collected in the Métabetchouane and Mistassini River, draining $35 \mathrm{~km}$ apart into Lake Saint-Jean. Adipose fins were clipped and preserved in 95\% ethanol. Thirty-six first-generation hatchery parr whose parents originated from both rivers were also obtained and preserved at $-80^{\circ} \mathrm{C}$.

Allozyme analysis involved only comparisons between hatchery samples as killing of wild fish was not possible. Analysis of muscle and liver was carried out on cellulose acetate (Hebert \& Beaton, 1989) for seven structural $\left(M D H-1^{*}, M D H-2^{*}, M D H-3^{*}\right.$, $\left.M D H-4^{*}, A A T-3^{*}, I D D H-1^{*}, I D D H-2^{*}\right)$ and one regulatory $\left(P G M-1 r^{*}\right)$ loci, known to be the most polymorphic for salmon in North America (Pollard, 1992; Verspoor, 1994).

MtDNA RFLP analysis was performed on three polymerase chain reaction (PCR) amplified segments using primers developed by Cronin et al. (1993) and Bernatchez \& Danzmann (1993). These encompassed the ND-5/6 $(2.4 \mathrm{~kb})$, the ND-1 $(2.0 \mathrm{~kb})$, and the cytochrome $b$ gene/D-loop $(2 \cdot 1 \mathrm{~kb})$ regions. PCR conditions were as in Bernatchez et al. (1995) except that the annealing temperature was $45^{\circ} \mathrm{C}$. Aliquots of the PCR products were digested with 19 restriction enzymes (AluI, AvalI, BanI, BanII, Bsp1286I, CfoI, DdeI, HaeII, HaeIII, HincII, HinfI, HpaII, MboI, MboII, MspI, NciI, RsaI, Sau3aI, TaqI). Electrophoresis and detection procedures were as described previously (Bernatchez et al., 1995). Genotypes were defined by composite patterns of restriction site variation across all enzymes and segments.

Microsatellite polymorphism was analysed by specific PCRs at four loci using primers developed for Salmo trutta L. ( $\mu 15$ : Estoup et al., 1993; $\mu 3, \mu 85, \mu 79 \cdot 1$ : Presa, unpublished data), and one locus (SFO-8) using primers developed for Salvelinus fontinalis Mitchill (Angers et al., 1995). PCR reactions with $S$. trutta primers were performed in $12 \mu \mathrm{l}$ reaction volume containing 1 unit of Taq polymerase, $1.25 \mu$ reaction buffer, 15 pmol each primers, $500 \mu \mathrm{M}$ of dNTP, $0 \cdot 15 \mu \mathrm{l}$ of $\alpha^{35} \mathrm{~S}-\mathrm{dATP}$ and $1 \mu 1(50-100 \mathrm{ng})$ of total DNA. We used the following profile in PCR: one denaturation at $95^{\circ} \mathrm{C}$ for $2 \mathrm{~min}$; 35 cycles of $35 \mathrm{~s}$ at $94^{\circ} \mathrm{C}, 35 \mathrm{~s}$ at annealing temperature $\left(\mu 3=57^{\circ} \mathrm{C}, \mu 15=58^{\circ} \mathrm{C}\right.$, $\mu 79 \cdot 1=59^{\circ} \mathrm{C}, \mu 85=55^{\circ} \mathrm{C}$ ), and $10 \mathrm{~s}$ at $72^{\circ} \mathrm{C}$. Conditions for the SFO-8 locus followed Angers et al. (1995). Migration, fixation, drying, and autoradiography followed standard procedures. Alleles were sized by comparison with the standard M13 sequence.

Genetic polymorphism for each sample was measured by Hardy-Weinberg expected heterozygosity $\left(H_{E}\right)$ at nuclear loci and by nucleon diversity index $(h)$ for mtDNA (Nei, 1987). The significance of differences in allele frequencies among samples was estimated by $\chi^{2}$ test of homogeneity. Variance in allele frequencies among samples was also estimated from $G_{\text {st }}$ calculations (Nei, 1987). The significance of $G_{\text {st }}$ values was tested using a random allelic permutation procedure (Excoffier et al., 1992). 


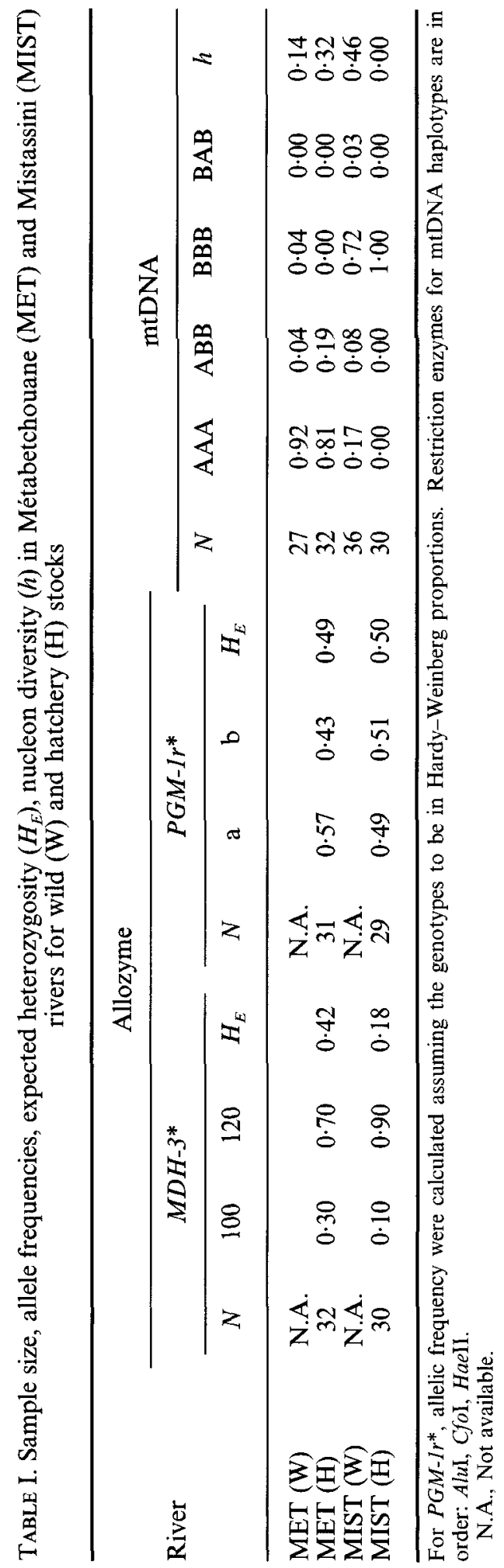




\section{RESULTS}

Low variation was detected in allozymes between hatchery samples originating from the Mistassini and Métabetchouane Rivers. Only two loci were polymorphic $\left(P_{0.99}\right)$ with two alleles detected in each case (Table I). Significant allele frequency difference was observed between tributaries only at $M D H-3^{*}$ $\left(\chi^{2}=7.46 ; P=0.007\right)$ which also translated into a significant $G_{\text {st }}$ estimate of 0.099 (Table III).

Low polymorphism was also observed in mtDNA. Only three of the 19 restriction enzymes used were variable. The ND-1 segment was polymorphic for $C f o \mathrm{I}$ and $H a e \mathrm{II}$ as was the cytochrome $b / \mathrm{D}$-loop segment for $A l u \mathrm{I}$. No variation was detected in the ND-5/ND-6 segment. Only four mtDNA composite genotypes were resolved such that nucleon diversity was low in all samples. However, genotypes segregated strongly between rivers $\left(\chi^{2}=36.25 ; P<0.001\right)$. Salmon from the Métabetchouane River were highly dominated by genotype AAA whereas those from the Mistassini River were dominated by genotype BBB (Table I). Consequently, a strong component $(61 \cdot 4 \%)$ of the total mtDNA gene diversity was due to population subdivision. A significant difference in the frequency of mtDNA genotypes was observed also between wild and hatchery

TABLE II. Allele frequencies and expected heterozygosity $\left(H_{E}\right)$ for $\mu 85, \mu 15$, SFO- $8, \mu 79 \cdot 1$ and $\mu 3$ microsatellite loci in Métabetchouane (MET) and Mistassini (MIST) rivers for wild (W) and hatchery $(\mathrm{H})$ stocks

\begin{tabular}{|c|c|c|c|c|c|c|c|c|c|c|}
\hline \multirow{2}{*}{$\begin{array}{l}\begin{array}{l}\text { Locus and } \\
\text { population }\end{array} \\
\mu 85\end{array}$} & \multirow[t]{2}{*}{$N$} & \multicolumn{3}{|c|}{ Alleles (named by } & \multicolumn{6}{|c|}{ size in base pairs) and their proportions } \\
\hline & & 162 & 170 & $H_{E}$ & & & & & & \\
\hline MET (W) & 30 & $0 \cdot 00$ & 1.00 & 0.00 & & & & & & \\
\hline MET (H) & 32 & 0.00 & 1.00 & 0.00 & & & & & & \\
\hline MIST (W) & 36 & $0 \cdot 18$ & 0.82 & $0 \cdot 30$ & & & & & & \\
\hline MIST (H) & 32 & 0.03 & 0.97 & 0.06 & & & & & & \\
\hline$\mu 15$ & & 218 & 220 & $H_{E}$ & & & & & & \\
\hline MET (W) & 30 & $0 \cdot 15$ & 0.85 & 0.26 & & & & & & \\
\hline $\operatorname{MET}(\mathrm{H})$ & 33 & $0 \cdot 35$ & 0.65 & 0.46 & & & & & & \\
\hline MIST (W) & 36 & 0.19 & $0 \cdot 81$ & $0 \cdot 31$ & & & & & & \\
\hline MIST (H) & 30 & $0 \cdot 17$ & 0.83 & $0 \cdot 28$ & & & & & & \\
\hline SFO-8 & & 200 & 206 & 210 & $H_{E}$ & & & & & \\
\hline $\operatorname{MET}(W)$ & 19 & 0.05 & 0.00 & 0.95 & $0 \cdot 10$ & & & & & \\
\hline $\operatorname{MET}(\mathrm{H})$ & 36 & 0.01 & 0.00 & 0.99 & 0.02 & & & & & \\
\hline MIST (W) & 31 & 0.00 & 0.03 & 0.97 & 0.06 & & & & & \\
\hline MIST (H) & 31 & 0.06 & 0.02 & 0.92 & $0 \cdot 15$ & & & & & \\
\hline$\mu 79 \cdot 1$ & & 149 & 151 & 153 & 155 & $H_{E}$ & & & & \\
\hline MET (W) & 28 & 0.57 & $0 \cdot 39$ & 0.00 & 0.04 & 0.53 & & & & \\
\hline MET (H) & 32 & 0.75 & $0 \cdot 25$ & 0.00 & 0.00 & 0.38 & & & & \\
\hline MIST (W) & 35 & $0 \cdot 20$ & 0.03 & $0 \cdot 56$ & $0 \cdot 21$ & 0.61 & & & & \\
\hline MIST (H) & 22 & 0.43 & 0.05 & $0 \cdot 39$ & $0 \cdot 14$ & 0.66 & & & & \\
\hline$\mu 3$ & & 202 & 204 & 206 & 208 & 210 & 212 & 214 & 216 & $H_{E}$ \\
\hline $\operatorname{MET}(\mathrm{W})$ & 19 & 0.02 & $0 \cdot 19$ & 0.03 & $0 \cdot 29$ & $0 \cdot 31$ & $0 \cdot 00$ & 0.03 & $0 \cdot 12$ & $0 \cdot 78$ \\
\hline MET (H) & 36 & $0 \cdot 30$ & $0 \cdot 12$ & 0.03 & $0 \cdot 12$ & $0 \cdot 17$ & $0 \cdot 10$ & $0 \cdot 17$ & 0.00 & 0.83 \\
\hline MIST (W) & 31 & $0 \cdot 00$ & $0 \cdot 00$ & 0.00 & 0.07 & 0.61 & 0.25 & 0.03 & 0.04 & 0.57 \\
\hline $\operatorname{MIST}(\mathrm{H})$ & 31 & $0 \cdot 00$ & $0 \cdot 00$ & 0.02 & $0 \cdot 28$ & 0.48 & $0 \cdot 21$ & 0.00 & 0.02 & 0.66 \\
\hline
\end{tabular}


TABLE III. Pairwise comparison of interpopulation diversity $\left(G_{\mathrm{st}}\right)$ estimated individually for each allozyme, mtDNA and microsatellite loci in Métabetchouane (MET) and Mistassini (MIST) rivers for wild (W) and hatchery $(\mathrm{H})$ stocks

\begin{tabular}{|c|c|c|c|}
\hline & MET $v$. MIST & $\operatorname{MET}(\mathrm{W}) v . \operatorname{MET}(\mathrm{H})$ & $\operatorname{MIST}(\mathbf{W}) v . \operatorname{MIST}(\mathrm{H})$ \\
\hline \multicolumn{4}{|l|}{ Allozyme } \\
\hline$M D H-3^{*}$ & $0.099 * *$ & N.A. & N.A. \\
\hline$P G M-1 r^{*}$ & 0.000 & N.A. & N.A. \\
\hline mtDNA & $0 \cdot 614 * *$ & 0.042 & $0 \cdot 164^{* *}$ \\
\hline \multicolumn{4}{|l|}{ Microsatellite } \\
\hline$\mu 85$ & $0 \cdot 155^{* *}$ & 0.000 & $0.094 *$ \\
\hline$\mu 15$ & 0.000 & $0.084^{*}$ & 0.000 \\
\hline SFO-8 & 0.006 & 0.008 & 0.015 \\
\hline$\mu 79 \cdot 1$ & $0 \cdot 341^{* *}$ & $0.041^{*}$ & $0.050^{* *}$ \\
\hline$\mu 3$ & $0 \cdot 146^{* *}$ & $0 \cdot 086 * *$ & $0.035^{*}$ \\
\hline
\end{tabular}

MET $v$. MIST only included comparison between first-generation hatchery parr for allozyme. Significance levels: ${ }^{*} 0.001<P<0 \cdot 05$; ${ }^{* *} P<0 \cdot 001$.

N.A., Not available.

samples from the Mistassini River $\left(\chi^{2}=9 \cdot 82 ; P=0 \cdot 006\right)$, translating into a significant $G_{\text {st }}$ value (Table III).

Microsatellites were polymorphic to various extents depending on locus (Table II). The number of alleles per locus varied between 2 and 8 while sample heterozygosity varied between 0 and $83 \%$. Highly significant differences $(P<0.001)$ in allele frequencies were observed between rivers at three loci $(\mu 3$ : $\left.\chi^{2}=50 \cdot 12 ; \mu 79 \cdot 1: \chi^{2}=71 \cdot 98 ; \mu 85: \chi^{2}=12 \cdot 02\right)$. Consequently, a significant component $(14 \cdot 6$ to $34 \cdot 1 \%)$ of the total genetic diversity was due to population subdivision (Table III). River-specific alleles were also detected at moderate frequencies for the three loci. For $\mu 3$, alleles 202 and 204 were observed only in Métabetchouane River, as were allele 162 at $\mu 85$ and allele 153 at $\mu 79 \cdot 1$ for the Mistassini River. Significant changes in allele frequencies between wild and firstgeneration hatchery salmon were observed also. Thus, allelic frequencies differed at loci $\mu 3\left(\chi^{2}=40.86 ; P<0.001\right), \mu 15\left(\chi^{2}=6.53 ; P=0.007\right)$ and $\mu 79.1$ $\left(\chi^{2}=5.64 ; P=0.035\right)$ between samples originating from the Métabetchouane River, whereas Mistassini samples differed at loci $\mu 3\left(\chi^{2}=13 \cdot 16 ; P=0.013\right)$ and $\mu 85\left(\chi^{2}=7 \cdot 70 ; P=0.004\right)$. Significant $G_{\text {st }}$ estimates were obtained also in all cases although the values were always smaller than inter-river comparisons (Table III).

No general trend in patterns of intra-sample genetic diversity was observed between wild and first-generation hatchery fish. For the Mistassini River, loss or reduction of less frequent alleles and lower diversity was detected in hatchery fish for mtDNA and microsatellite $\mu 85$, whereas no obvious changes in number of alleles and similar or higher diversity was observed at other loci and for the Métabetchouane fish at all loci (Tables I, II). However, important shifts in allele frequencies were observed in both rivers, for mtDNA and microsatellite $\mu 15$ and $\mu 3$.

\section{DISCUSSION}

Altogether, the three genetic markers used indicated an important genetic differentiation between two landlocked salmon populations of Lake Saint-Jean. 
Thus, unique or dominant alleles, highly significant differences in allele frequencies and high $G_{\text {st }}$ values were observed. This supported the hypothesis that the two rivers, perhaps through homing behaviour, harbour distinctive genetic populations that fulfil the main prerequisite for local adaptation (Hindar et al., 1991; Carvalho, 1993). Highly significant shifts in allele frequency between wild and hatchery stocks were detected also. Other studies indicated that breeding in the hatchery was responsible for such changes (Verspoor, 1988). Such conclusions cannot be made in the present case as allelic fluctuation through genetic drift is expected in small populations. Therefore, a firmer assessment of the breeding effect on genetic diversity of landlocked salmon from Lake Saint-Jean must await further comparisons among generations of wild populations.

Allozyme analysis showed very low polymorphism. Only two loci were variable, allowing the determination of weak differences in allele frequencies and a relatively low $G_{\mathrm{st}}$ value. We cannot refute the possibility that we observed low variation because comparisons were made on hatchery fish only. Nevertheless, these results fit the general pattern of low variation at protein loci in the species (Davidson et al., 1989; Verspoor, 1994). However, the main constraint with the use of allozymes in our study was that the method necessitates killing which was not compatible with the goal of preserving already threatened populations. This may represent a general drawback of the technique for any study dealing with endangered populations (Park \& Moran, 1994).

Very little variation in the number of haplotypes was observed in mtDNA, as usually reported for Atlantic salmon (e.g. Bermingham, 1990; King et al., 1993). It may be argued that the low variability observed in mtDNA was due to the use of RFLP analysis as it is increasingly reported that direct sequencing provides greater resolution (Carr \& Marshall, 1991). However, this may not be exclusively so in salmonids. For instance, sequencing of the D-loop, generally considered the most variable region in the mitochondrial genome, was monomorphic among S. trutta populations of the European North Atlantic basin, yet RFLP analysis revealed many haplotypes among the same populations (Hall, 1992; Hall \& Nawrocki, 1995). In a study of brook charr no difference was observed in the number of mtDNA genotypes detected by RFLP or sequence analysis of the D-loop region (Bernatchez \& Danzmann, 1993). Therefore it appears unlikely that sequencing would have generated more variation than RFLP, unless intense analytical effort was applied. Despite its low diversity, mtDNA was the most discriminating marker between wild populations, as exemplified by the high $G_{\text {st }}$ value observed. This can be explained partly by the fact that maternally inherited mtDNA is more sensitive to genetic drift than nuclear DNA due to its smaller effective population size (Takahata \& Slatkin, 1984).

Microsatellite analysis proved to be useful, both for detecting variation between populations and changes in allelic composition between wild and hatchery stocks. In some loci, population unique alleles were found at moderate frequencies which enhanced their discrimination. The polymophic loci were useful in detecting changes in the number of alleles and were more sensitive to find variation between wild and hatchery stocks. Although high genetic diversity was detected with the loci used, microsatellite analysis could be improved by including new loci and by using specific microsatellite primers for Atlantic salmon (Wright \& Bentzen, 1994). 
In summary, allozyme analysis was the most limited approach to reach our specific objectives as both sufficient resolution and the sample acquisition were limited. Although low variation was detected in mtDNA, it was the most discriminatory locus between wild populations. Microsatellites appear to be promising due to their high sensitivity in differentiating wild populations, in detecting changes in allele composition, and potential for increased resolution. Microsatellite and mtDNA methods also had the advantage of requiring only minute and non-destructive amounts of tissue. Given the benefits and disadvantages of the three methods, it appears that a combination of mtDNA and microsatellite analyses would address best the objectives of our ongoing research on the conservation genetics of $S$. salar.

We thank the personnel of Centre Écologique du lac St-Jean, Omer Gauthier and other employees from the Ministère de l'Environnement et de la Faune du Québec, for their help in collecting specimens; Albert Craig and Grégoire Y. Maynard for helpful comments; and Jonathan Scheibe for technical assistance. This study was supported by NSERC (Canada) and FCAR (Québec) research grants to L.B. Contribution program of GIROQ (Groupe Interuniversitaire de Recherches Océanographiques du Québec).

\section{References}

Angers, B., Bernatchez, L., Angers, A. \& Desgroseillers, L. (1995). Specific microsatellite loci for brook charr reveals strong population subdivision on microgeographic scale. Journal of Fish Biology 47 (Suppl. A), 177-185.

Bermingham, E. (1990). Mitochondrial DNA and the analysis of fish population structure. In Electrophoretic and Isoelectric Focusing Techniques in Fisheries Management (Whitmore, D. H., ed.), pp. 197-221. Boston, MA: CRC Press.

Bernatchez, L. (1994). Techniques de biologie moléculaire comme outils de gestion des pêches: bilan et perspectives. Bulletin Français de la Pêche et de la Pisciculture 332, $1-9$.

Bernatchez, L., Glémet, H., Wilson, C. \& Danzmann, R. G. (1995). Fixation of introgressed mitochondrial genome of Arctic charr (Salvelinus alpinus (L.)) in an allopatric population of brook charr (Salvelinus fontinalis Mitchill). Canadian Journal of Fisheries and Aquatic Sciences 52, 179-185.

Bernatchez, L. \& Danzmann, R. G. (1993). Congruence in control-region sequence and restriction-site variation in mitochondrial DNA of brook charr (Salvelinus fontinalis Mitchill). Molecular Biology and Evolution 10, 1002-1014.

Billington, N. \& Hebert, P. D. N. (1991). Mitochondrial DNA diversity in fishes and its implications for introductions. Canadian Journal of Fisheries and Aquatic Sciences 48 (Suppl. 1), 80-94.

Carvalho, G. R. (1993). Evolutionary aspects of fish distribution: genetic variability and adaptation. Journal of Fish Biology 43 (Suppl. A), 53-73.

Carvalho, G. R. \& Hauser, L. (1994). Molecular genetics and the stock concept in fisheries. Reviews in Fish Biology and Fisheries 4, 326-350.

Carr, S. M. \& Marshall, H. D. (1991). Detection of intraspecific DNA sequence variation in the mitochondrial cytochrome $b$ gene of Atlantic cod (Gadus morhua) by the polymerase chain reaction. Canadian Journal of Fisheries and Aquatic Sciences 48, 48-52.

Cronin, M. A., Spearman, W. J., Wilmot, R. L., Patton, J. C. \& Bickham, J. W. (1993). Mitochondrial DNA variation in chinook (Oncorhynchus tshawytscha) and chum salmon $(O$. keta) detected by restriction enzyme analysis of polymerase chain reaction (PCR) products. Canadian Journal of Fisheries and Aquatic Sciences 50, $708-715$. 
Davidson, W. S., Birt, T. P. \& Green, J. M. (1989). A review of genetic variation in Atlantic salmon, Salmo salar L., and its importance for stock identification, enhancement programmes and aquaculture. Journal of Fish Biology 34, 547-560.

Estoup, A., Presa, P., Krieg, F., Vaiman, D. \& Guyomard, R. (1993). (CT) and (GT) microsatellites: a new class of genetic markers for Salmo trutta L. (brown trout). Heredity 71, 488-496.

Excoffier, L., Smouse, P. E. \& Quattro, J. M. (1992). Analysis of molecular variance inferred from metric distances among DNA haplotypes: application to human mitochondrial DNA restriction data. Genetics 131, 479-491.

Ferguson, M. (1994). The role of molecular genetic markers in the management of cultured fishes. Reviews in Fish Biology and Fisheries 4, 351-373.

Hebert, P. D. N. \& Beaton, M. J. (1989). Methodologies for Allozyme Analysis Using Cellulose Acetate Electrophoresis (Helena Laboratories, eds). Ontario: University of Windsor.

Hindar, K., Ryman, N. \& Utter, F. (1991). Genetic effects of cultured fish on natural fish populations. Canadian Journal of Fisheries and Aquatic Sciences 48, 945-957.

Hall, H. J. (1992). The genetics of brown trout (Salmo trutta L.) populations in Wales. $\mathrm{PhD}$ Thesis, University of Wales.

Hall, H. J. \& Nawrocki, L. W. (1995). A rapid method for detecting mitochondrial DNA variation in the brown trout, Salmo trutta. Journal of Fish Biology 46, 360-364.

King, D. P. F., Hovey, S. J., Thompson, D. \& Scott, A. (1993). Mitochondrial DNA variation in Atlantic salmon, Salmo salar L., populations. Journal of Fish Biology 42, 25-33.

Nei, M. (1987). Molecular Evolutionary Genetics. New York: Columbia University Press.

Park, L. K. \& Moran, P. (1994). Developments in molecular genetic techniques in fisheries. Reviews in Fish Biology and Fisheries 4, 272-299.

Pollard, S. M. (1992). The significance of variation at a regulatory locus $P G M-1 r^{*}$ and five structural loci on the life histories of Oncorhynchus mykiss and Salmo salar. Master's thesis. University of Guelph, Ontario.

Ryman, N. (1991). Conservation genetics considerations in fishery management. Journal of Fish Biology 39 (Suppl. A), 211-224.

Taggart, J. B. \& Ferguson, A. (1990). Hypervariable minisatellite DNA single locus probes for the Atlantic salmon, Salmo salar L. Journal of Fish Biology 37, 991993.

Takahata, N. \& Slatkin, M. (1984). Mitochondrial gene flow. Proceedings of the National Academy of Sciences of the USA. 81, 1764-1767.

Verspoor, E. (1988). Reduced genetic variability in first-generation hatchery populations of Atlantic salmon (Salmo salar). Canadian Journal of Fisheries and Aquatic Sciences 45, 1686-1690.

Verspoor, E. (1994). The evolution of genetic divergence at protein coding loci among anadromous and non anadromous populations of Atlantic salmon Salmo salar. In Genetics and Evolution of Aquatic Organisms (Beaumont, A. R., ed.), pp. 52-66. London: Chapman \& Hall.

Wright, J. M. \& Bentzen, P. (1994). Microsatellites: genetic markers for the future. Reviews in Fish Biology and Fisheries 4, 384-388. 